Participative Journal: Jurnal Pengabdian Pada Masyarakat

Vol. 01, No. 02, September 2021 | Page 59-70

E-ISSN 2776-2971, P-ISSN 2776-5954

Journal homepage: https://jurnal.jurmat.com/index.php/pj/index

\title{
Keterlibatan KKP-DR UIN Mataram pada masa pandemi Covid-19 dalam upaya mewujudkan kampung sehat di Desa Batutulis
}

\author{
Suparmanto $^{1 *}$, Tri Mulyalestari ${ }^{2}$ \\ *Affiliasi: Universitas Islam Negeri Mataram
}

\section{Keywords:}

Student

involvements,

public,

Covid-19, healthy village
$\boldsymbol{A} \boldsymbol{b} \boldsymbol{s} \boldsymbol{t} \boldsymbol{r} \boldsymbol{a} \boldsymbol{c} \boldsymbol{t}$ : Covid-19 is a disease caused by a new type of corona virus that first appeared in Wuhan, China at the end of 2019. Symptoms of Covid-19 are cough, fever, and shortness of breath. Covid-19 infection causes quite high mortality in various countries, including Indonesia. Covid-19 has also changed all aspect which has become a prolonged crisis mus immediately find a solution so that it does not have an even greater impact. One of the efforts made by the government to prevent the spread of the Corona-19 virus is by implementing restrictions on community activities that take place in regions in Indonesia. Another government institution that is also involved in minimizing the impact of Covid-19 is UIN Mataram. The involvement of UIN Mataram in this case is to direct its students to carry out Participatory Work From Home Lectures. The implementation of the Participatory Work From Home is focused on aspects of education and health. However, the priority is in the health aspect. In Batutulis Village, Jonggat, Central Lombok, various efforts were made by students on health aspect. Where this is in line with the goal of the Batutulis Village Head to create a healthy village. Healthy in this case is not only physically and spiritually healthy but also the environment in which it is occupied is also healthy. So the effort made are to carry out mutual cooperation in cleaning the environment such as ditches and rivers which are often used as garbage dumps, cleaning mosques, doing healthy exercise with the community and socializing the prevention of the spread of Covid-19.

A b s t r a k: Covid-19 merupakan penyakit akibat virus corona jenis baru yang muncul pertama kali di Wuhan, Cina pada akhir tahun 2019. Gejala dari Covid-19 yaitu batuk, demam, dan sesak napas. Infeksi Covid-19 menyebabkan kematian yang cukup tinggi di berbagai Negara, termasuk Indonesia. Covid-19 ini juga telah merubah semua aspek kehidupan, terutama aspek kesehatan yang menjadi krisis berkepanjangan. Adanya krisis kesehatan ini harus segera dicarikan solusi agar tidak memberikan dampak yang lebih besar lagi. Salahsatu upaya yang dilakukan pemerintah untuk mencegah penyebaran virus Corona-19 ini yaitu dengan pemberlakuan pembatasan kegiatan masyarakat (PPKM) yang berlangsung
Kata Kunci:

Keterlibatan mahasiswa, masyarakat, Covid-19, kampung sehat

\footnotetext{
${ }^{1}$ Coresponden to author: Fakultas Tarbiyah dan Keguruan, Universitas Islam Negeri Mataram, Jl. Gajah Mada Jempong, Indonesia. (83116), e-mail addresses: suparmanto@uinmataram.ac.id

2 E-mail addresses: mulyalestari@gmail.com
}

Suparmanto, dkk (2021), Keterlibatan KKP-DR UIN Mataram pada masa pandemi ... | Vol. 01, No.02, 2021 | h. 59 
diwilayah di Indonesia. Adapun Lembaga pemerintah lainnya yang turut terlibat dalam hal meminimalisisr dampak Covid-19 adalah UIN Mataram. Keterlibatan UIN Mataram dalam hal ini adalah mengarahkan mahasiswanya untuk melaksanakan Kuliah Kerja Partisipatif Dari Rumah (KKP-DR). Pelaksanaan KKP-DR difokuskan pada aspek Pendidikan dan kesehatan. Namun yang lebih di utamakan dalam aspek kesehatan. Di Desa Batutulis, Jonggat, Lombok Tengah berbagai upaya dilakukan oleh mahasiswa pada aspek kesehatan. Dimana hal ini selaras dengan tujuan dari Kepala Desa Batutulis untuk mewujudkan kampung sehat. Sehat dalam hal ini bukan saja sehat fisik, jasmani, dan rohani namun juga lingkungan yang ditempati juga sehat. Maka upaya yang dilakukan yaitu melakukan gotong royong pembersihan lingkungan seperti selokan dan sungai yang sering dijadikan tempat pembuangan sampah, pembersihan masjid-masjid, melakukan senam sehat bersama masyarakat serta sosialisasi pencegahan penyebaran Covid19.

\section{Pendahuluan}

Pada tahun 2021, Kuliah Kerja Partipatif (KKP) dilaksanakan dari rumah (DR). KKP adalah salahsatu mata kuliah yang wajib diikuti oleh seluruh mahasiswa UIN Mataram. KKP ini dilaksanakan pada libur semester 6. Kegiatan KKP dibimbing oleh Dosen Pembimbing Lapangan (DPL) dengan lokasi di wilayah yang menjadi sasaran pelaksanaan KKP. Kegiatan KKP dilakukan selama 45 Hari yaitu sejak tanggal 2 Juli 2021 s/d 15 Agustus 2021. KKP bertujuan untuk membekali mahasiswa dalam mengaplikasikan keilmuan yang telah dipelajari selama perkuliahan. Secara khusus, KKP ini dilakukan untuk melibatkan mahasiswa dalam hal memecahkan berbagai fenomena atau permasalahan yang ada di masyarakat melalui pengembangan potensi yang ada pada masyarakat.

Covid-19 merupakan penyakit akibat virus corona yang muncul pertama kali di Wuhan, Cina pada akhir tahun 2019. Gejala dari Covid-19 yaitu batuk, demam, dan sesak napas. Infeksi Covid-19 menyebabkan kematian yang cukup tinggi di berbagai Negara, termasuk Indonesia. Covid-19 ini juga telah merubah semua aspek kehidupan, terutama aspek kesehatan yang menjadi krisis berkepanjangan. Adanya krisis kesehatan ini harus segera dicarikan solusi agar tidak memberikan dampak yang lebih besar lagi. Salah satu solusi yang dapat dilakukan untuk pencegahan penyebaran covid-19 harus dimulai dari diri kita sendiri. Caranya dengan menerapkan perilaku hidup bersih dan sehat (PHBS). PHBS adalah semua perilaku yang dilakukan atas kesadaran sehingga anggota keluarga dapat menolong dirinya sendiri di bidang kesehatan dan berperan aktif dalam kegiatan-kegiatan kesehatan di masyarakat.

Perilaku hidup bersih dan sehat (PHBS) berkaitan erat dengan pencegahan penyebaran covid-19. Beberapa cara mencegah risiko terinfeksi covid-19, yaitu dengan mencuci tangan, menggunakan air dan sabun atau menggunakan cairan pembersih tangan (minimal 70\% alcohol), mencuci tangan merupakan salahsatu indicator PHBS. Selain itu protocol yang harus dilaksanakan yaitu menggunakan masker bila berpergian, menjaga jarak, hindari menyentuh

Suparmanto, dkk (2021), Keterlibatan KKP-DR UIN Mataram pada masa pandemi ... | Vol. 01, No.02, 2021 | h. 60 
wajah karena mulut, hidung, mata dapat menjadi pintu masuk virus, bersihkan benda, permukaan, dan alat-alat yang sering digunakan khususnya yang digunakan secara umum, mengkonsumsi makanan bergizi seimbang, tidak merokok, istirahat secara teratur, berolahraga serta berfikir positif. Ikuti arahan dan informasi dari petugas kesehatan dan Dinas Kesehatan setempat, serta taati aturan dari pemerintah.

Mentaati aturan dari pemerintah untuk mencegah penyebaran virus Corona-19 ini dapat dilakukan oleh masyarakat dengan melakukan vaksin dan mentaati adanya pemberlakuan pembatasan kegiatan masyarakat (PPKM) yang berlangsung di wilayah di Indonesia. Adapun Lembaga pemerintah yang turut terlibat dalam hal meminimalisir dampak Covid-19 adalah UIN Mataram. Keterlibatan UIN Mataram dalam hal ini adalah mengarahkan mahasiswanya untuk melaksanakan Kuliah Kerja Partisipatif Dari Rumah (KKP-DR). Pelaksanaan KKP-DR difokuskan pada aspek Pendidikan dan kesehatan. Namun yang lebih di utamakan dalam aspek kesehatan. Di Desa Batutulis, Jonggat, Lombok Tengah berbagai upaya dilakukan oleh mahasiswa pada aspek kesehatan. Mengingat di Desa Batu Tulis terdapat masyarakat yang terpapar Covid-19 dan aspek kesehatan ini jugaberkaitan dengan tujuan dari Kepala Desa Batutulis untuk mewujudkan kampung sehat.

Kampung sehat adalah suatu kampung yang memiliki kondisi bersih, nyaman, aman, dan sehat. Tujuan dari adanya kampung sehat adalah menciptakan suatu masyarakat yang mandiri untuk hidup sehat melalui kampung sehat yang berbasis perilaku hidup bersih dan sehat. Selain itu juga untuk memberdayakan anggota rumah tangga agar tahu, mau, dan mampu mempraktekkan perilaku hidup bersih dan sehat serta berperan aktif dalam gerakan kesehatan di masyarakat. Karena memang masyarakat di Desa Batutulis masih memiliki kebiasaan untuk membuang sampah sembarangan terutama di selokan dan terutama di sungai. Sungai di Desa Batuttulis yang dulunya dikenal bersih dan digunakan sembagai tempat menyunyi baju dan mandi oleh masyarakat kini telah burubah menjadi sungai yang kotor. Sungai banyak tercermari oleh sampah plastic serta sampah popok bayi. Akibatnya pada musim penghujan aliran air sungai terhambat dan menyebabkan banjir.

Maka upaya yang dilakukan untuk mewujudkan kampung sehat di tengah pandemic Covid19 yaitu melakukan gotong royong bersaa masyarakat dalam pembersihan lingkungan seperti selokan dan sungai yang sering dijadikan tempat pembuangan sampah, pembuatan plang pencegahan pembuatan sampah sembarangan, pembersihan masjid-masjid, melakukan senam sehat bersama masyarakat serta sosialisasi pencegahan penyebaran Covid-19.

\section{Metode}

Keterlibatan Mahasiswa KKP-DR UIN Mataram pada masa Pandemi Covid-19 dalam program kesehatan di Desa Batutulis, Kecamatan Jonggat, Lombok Tengah ini dilaksanakan dengan cara: (1) melakukan sosialisasi program-program KKP-DR UIN Mataram pada pihak desa, (2) melakukan pemetaan program berdasarkan informasi dari desa,(3) menyiapkan sumber daya manusia dan materi, (4) melaksanakan edukasi kepada masyarakat terkait pencegahan penyebaran Covid-19. Sosialisasi dilakukan program dilakukan setelah mahasiswa diterima oleh

Suparmanto, dkk (2021), Keterlibatan KKP-DR UIN Mataram pada masa pandemi ... | Vol. 01, No.02, 2021 | h. 61 
pihak desa untuk melakukan KKP-DR. Berdasarkan informasi yang telah diperoleh dari desa, mahasiswa melakukan pemetaan program apa saja yang akan dilaksanakan. Hal ini bertujuan agar program yang dilaksanakan sesuai dengan harapan. Setelah dilakukan pemetaan program, maka kegiatan selanjtnya adalah mahasiswa mempersiapkan berbagai hal yang diperlukan dalam melaksanaka program kedepannya, baik mempersiapkan diri maupun materi. Terakhir, mahasiswa melaksankan berbagai program untuk mewujudkan kampung sehat termasuk didalamnya edukasi masyarakat mengenai pencegahan penyebaran Covid-19.

\section{Hasil dan Pembahasan}

Desa Batutulis merupakan salah satu desa dari 13 desa yang ada di wilayah Kecamatan Jonggat, Kabupaten Lombok Tengah, Nusa Tenggara Barat. Desa Batu tulis memiliki lima Dusun. Yaitu Dusun Batutulis, Dusun Jereneng, Dusun Bangket Gawah, Dusun Gontoran, dan Dusun Bunje. Desa Batutulis berada di wilayah seluas $\pm 311 \mathrm{Ha} / 28,28 \mathrm{~km}$, terdiri dari areal persawahan seluas $\pm 119 \mathrm{Ha}$, areal permukiman seluas $\pm 101 \mathrm{Ha}$, areal perkuburan $\pm 3,5 \mathrm{Ha}$, areal perkantoran $\pm 3,6 \mathrm{Ha}$, dan prasarana umum lainnya \pm 48,32 Ha. Letak desa Batutulis sebelah tara berbatasan dengan desa Jelantik, sebelah timur berbatasan dengan desa Nyerot, sebelah selatan berbatasan dengan desa Sukarara dan sebelah barat berbatasan dengan desa Abulia.

Keadaan topografi desa Batutulis dilihat secara umum merupakan daerah dataran rendah yang beriklim sebagaimana desa-desa lain di kabupaten Lombok Tengah dan mempunyai iklim kemarau, pancaroba, dan penghujan. Hal tersebut mempunyai pengaruh langsung terhadap pola tanam pertanian yang ada di desa Batutulis. Kehadiran kami di Desa Batutulis, Alhamdulillah disabut oleh masyarakat dengan antusias, keramahtamahan dari masyarakat terutama dari Kepala dusun dan pemuka agama membuat kami begitu betah. Bahkan kami dianggap sebagai anak sendiri oleh masyarakat.Hal inilah yang menambah semangat kami untuk melaksanakan program kerja yang telah kami susun dengan sebaik-baiknya dan tentunya agar tepat sasaran. Di lokasi KKP kami alhadulillah tidak terlalu mendapatkan kesulitan untuk melaksanakan program dan aktifitas di Desa. Hal ini tentunya tidak terlepas dari support Kepala Desa, Kepala Dusun, Babinza, para remaja dan adik-adik Desa Batutulis yang turut berpartisipasi dalam program yang kami jalankan.

Keterlibatan mahasiswa KKP-DR UIN Mataram pada masa pandemic Covid-19 cukup berpengaruh dalam mewujudkan kampung sehat di Desa Batutulis. Pengaruh yang dimaksud adalah mulai timbulnya kesadaran masyarakat untuk menjaga kebersihan dengan tidak membuang sampah sembarangan terutama di selokan dan sungai. Kebiasaan masyarakat yang sering membuang sampah sembarangan terutama sampah non organikberupa popok bayi ke sungai menimbulkan masalah yang cukup serius. Akibat dari pembungan sampah sembarangan ini menyebabkan aliran air sunagai menjadi terhambat dan pada akhirnya penyebabkan banjir. Selain adanya perubahan dari kebiasaan masyarakat yang bisa di bilang kurang baik yang kini mulai berkurang sedikit demi sedikit. Masyarakat yang abai terhadap protocol kesehatan, sekarang sedikit demi sedikitmasyarakat mulai mentaati protocol kesehatan seperti mengenakan

Suparmanto, dkk (2021), Keterlibatan KKP-DR UIN Mataram pada masa pandemi ... | Vol. 01, No.02, 2021 | h. 62 
masker dan protocol kesehatan lainnya karena di Desa Batutulis terdapat beberapa masyarakat yang dinyatakan positif Covid-19 dan hal ini tentu saja di khawatirkan akan menyebar di masyarakat lainnya.

Berdasarkan observasi dan informasi dari berbagai sumber, mahasiswa KKP-DR di Desa Batutulis berinisiatif mensosialisasikan serta melakukan upaya pencegahan penyebaran covid-19 serta mewujudkan kampung sehat melalui pihak desa, yaitu kepala desa dan jajarannya. Inisiatif tersebut terkait dengan program kerja yang akan dilakukan dan yang telah dipilih serta sejalan dengan permasalahan yang dihadapi. Kepada pihak desa, mahasiswa menawarkan berbagai program, namun lebih ditekankan ke program kesehatan. Program inilah yang akan dimaksimalkan sehingga memberikan dampak dan manfaat bagi masyarakat. Berikut diuraikan satu per satu.

\section{Program pencegahan penyebaran Covid-19}

\section{Penyebaran Pamflet}

Mahasiswa KKP-DR UIN Mataram melakukan penyebaran pamflet. Penyebaran pamflet dilakukan untuk mengedukasi masyarakat terkait virus Corona-19. Penyebaran pamflet ini bekerja sama dengan Kepala Desa, dimana penyebaran pamflet dilakukan di beberapa titik yang dianggap strategis dan efektif dijangkau oleh masyarakat. Penyebaran pamflet juga bekerja sama dengan Kepala SDN Batutulis, dimana kami juga menyebar pamflet di SDN Batutulis.

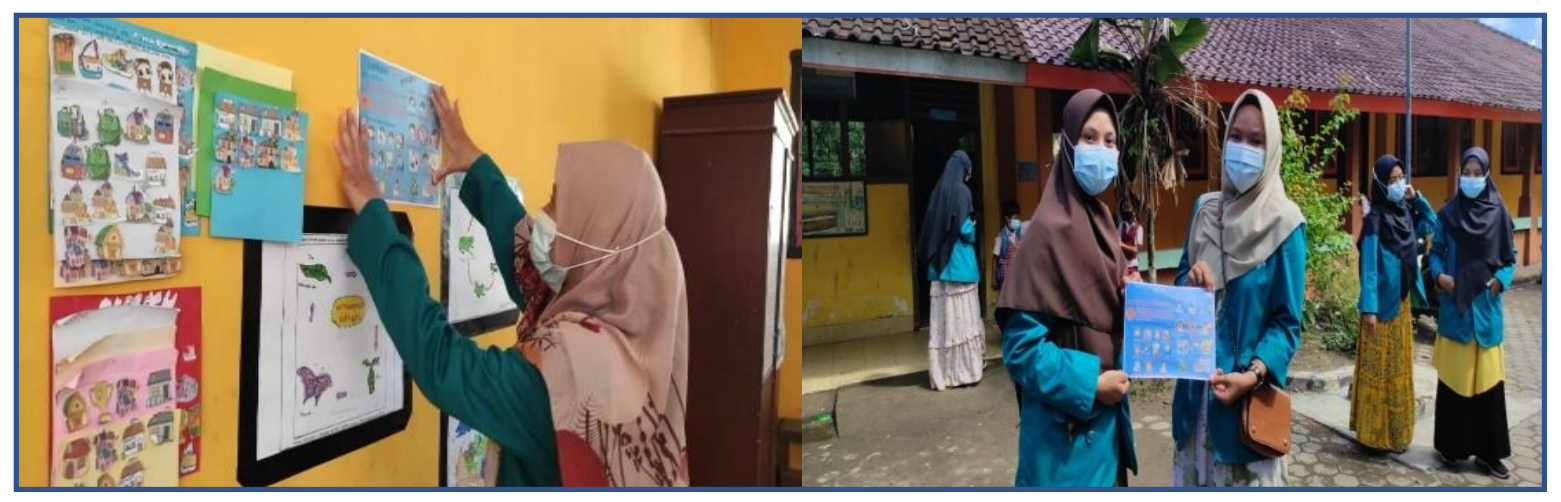

\section{Gambar 1: Penyebaran Pamflet}

\section{Pembagian masker}

Selain mengedukasi masyarakat Desa Batutulis dengan melakukan penyebaran pamplflet mengenai virus Covid-19, mahasiswa juga melakukan pembagian masker kepada masyarakat. Masker dibagikan agar masyarakat bisa menggunakannnya saat beraktifitas di luar rumah. Dengan adanya pembagian masker ini diharapkan dapat menumbuhkan kesadaran masyarakat untuk menggunakan masker sebagai langkah pencegahan penyebaran virus Covid-19. Adapun pembagian masker dilakukan saat adanya kegiatan posyandu di Dusun Desa Batutulis, selain itu pembagian masker juga dilakukan ketika mahasiswa mengadakan event besar seperti peringatan

Suparmanto, dkk (2021), Keterlibatan KKP-DR UIN Mataram pada masa pandemi ... | Vol. 01, No.02, 2021 | h. 63 
hari anak Nasional dan kegiatan lainnya. Selain pembagian masker tersebut mahasiswa juga mensosialisasikan agar tetap menjaga jarak dan tidak berkerumun agar kegiatan berjalan kondusif.

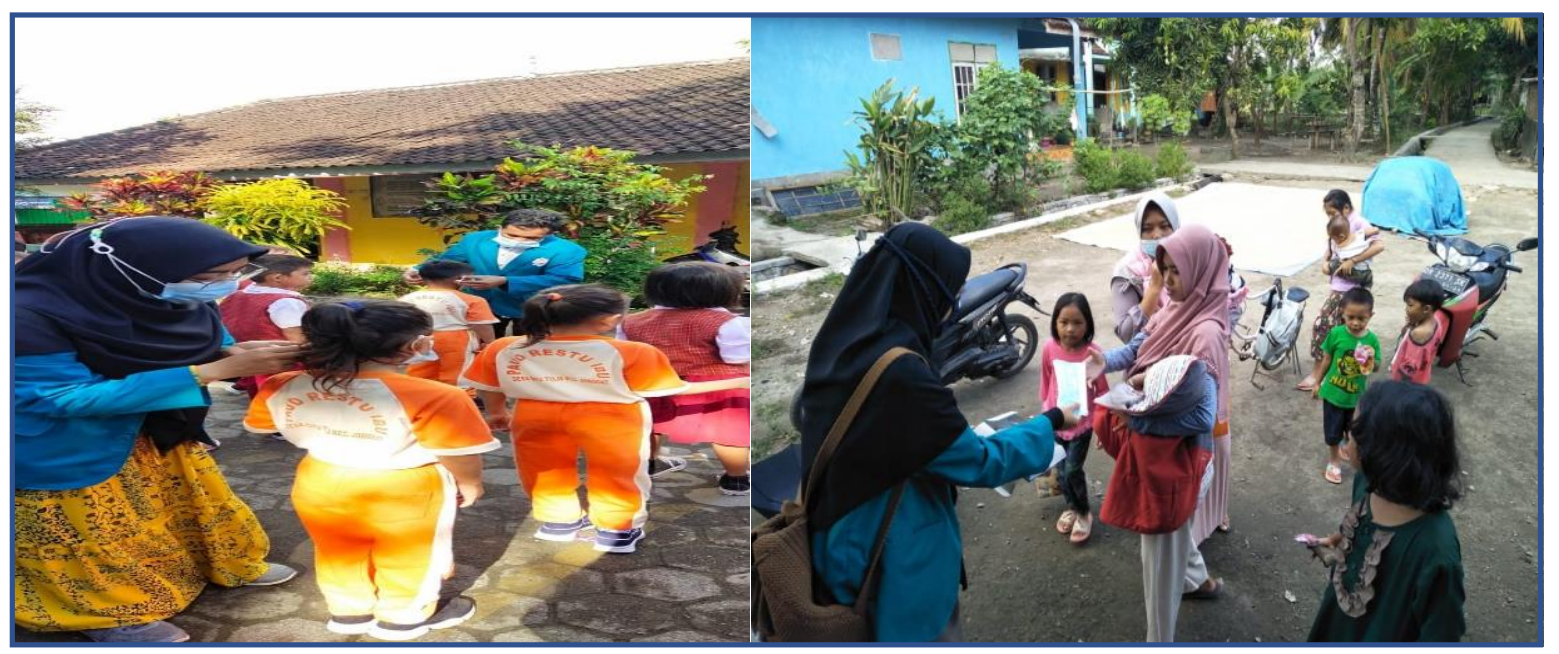

Gambar 2: Pembagian masker dan Pembagian hand sanitizer

Mahasiswa juga melakukan pembagian hand sanitizer di beberapa tempat. Pembagian di lakukan di Paud Al-Hikam, Paud Al-Ansar, di SDN Desa Batutulis, dan MI Sunan Ampel.

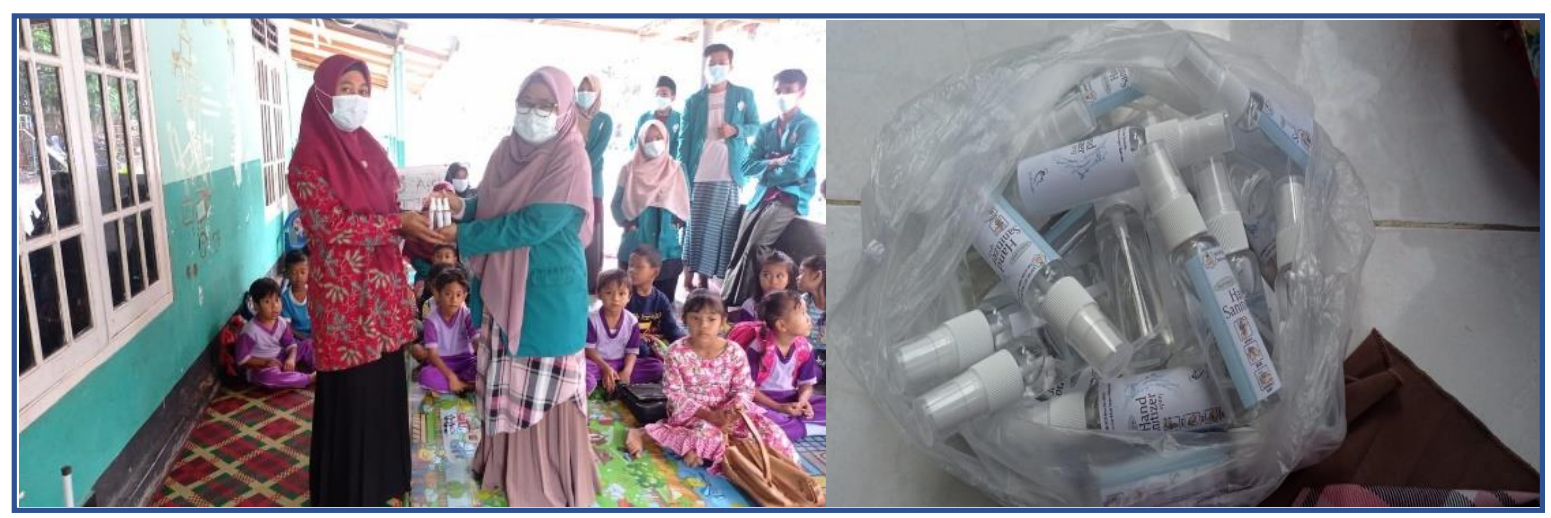

Gambar 3: Pembagian hand sanitizer

Sosialisasi Cara Cuci Tangan Yang Baik Dan Benar

Selain kegiatan penyebaran pamflet, pembagian masker, pembagian hansanitizer, mahasiswa juga mensosialisasikan untuk tetap mencuci tangan. Mencuci tangan dapat dijadikan langkah mencegah penyebaran virus Corona-19, jika masyarakat tidak memiliki hand sanitizer. Sosialisasi di lakukan di beberapa tempat seperti di Paud dan SDN di Batutulis. Dalam sosialisai ini mahasiswa mempraktekkan langsung cara mencuci tangan yang baik dan benar menurut WHO (World Healt Organization).

Suparmanto, dkk (2021), Keterlibatan KKP-DR UIN Mataram pada masa pandemi ... | Vol. 01, No.02, 2021 | h. 64 


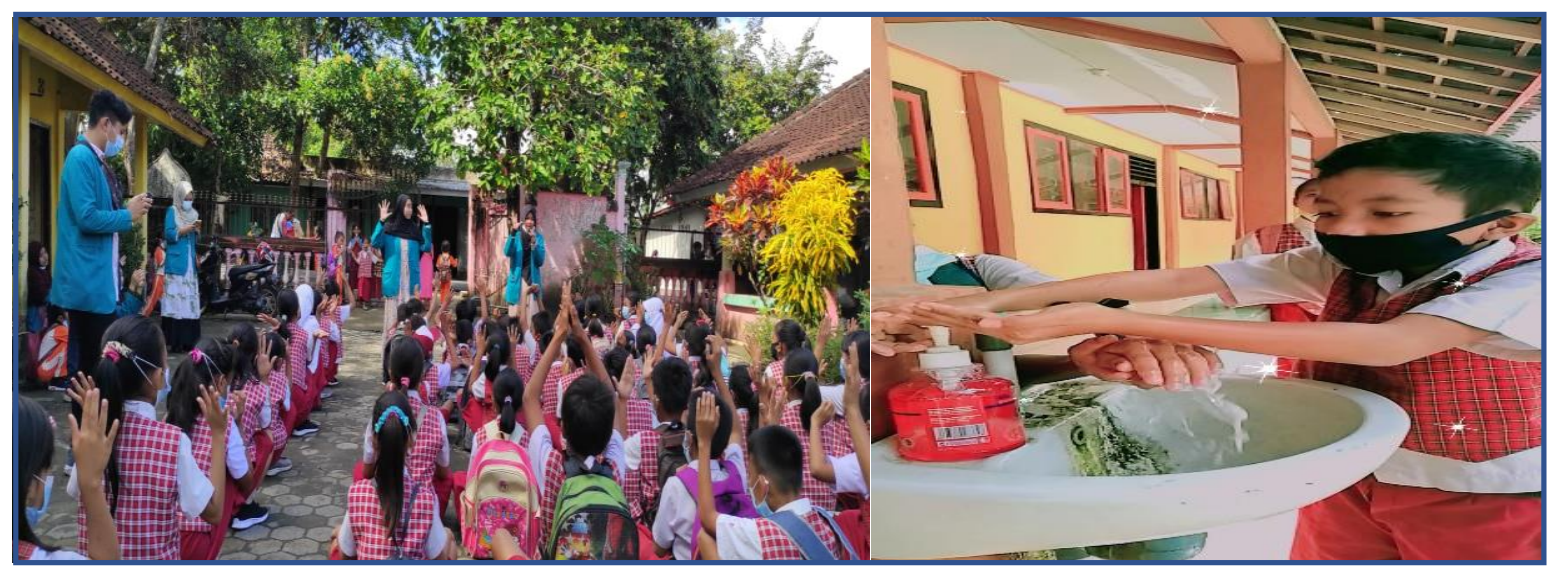

Gambar 4: Sosialisasi cara mencuci tangan yang baik dan benar

\section{Senam sehat}

Kegiatan senam sehat dilakukan empat kali dalam seminggu. Yakni dari hari senin sampai dengan hari kamis. Kegiatan senam sehat ini dilakukan dengan tetap mentaati protocol kesehatan. Senam sehat dilakukan dengan sasaran yaitu masyarakat dan adik-adik Dusun Bangket Gawah yang bertujuan untuk meningkatkan kebugaran jasmani masyarakat serta adik-adik Bangket Gawah mengingat sekarang masa pandemic covid-19 jadi perlu melakukan olahraga salahsatunya yaitu kegiatan senam ini. Harapan dari adanya senam ini semoga menjadi kebiasaan yang baik bagi masyarakat untuk tetap menjaga kesehatan.

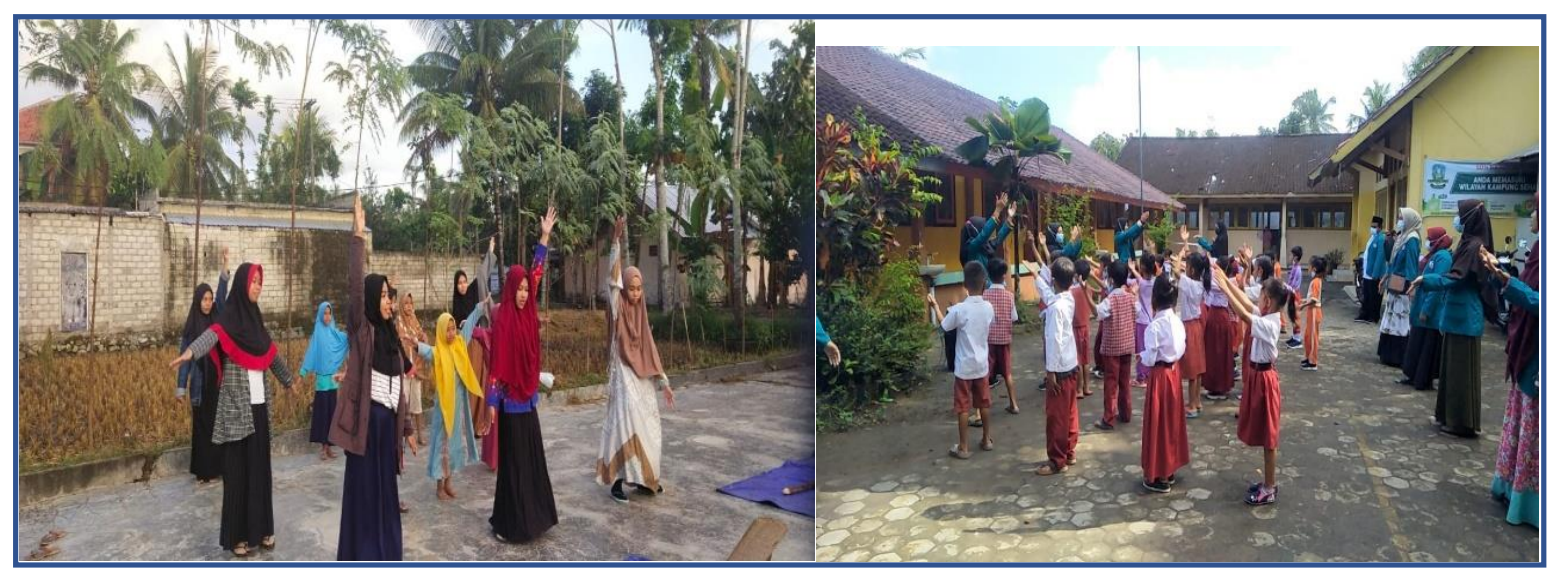

Gambar 5: Senam sehat

\section{Program dalam mewujudkan kampung sehat}

\section{Gotong royong di sepanjang jalan}

Kegiatan gotong royong di jalan sekitar kantor Desa Batutulis. Adapun tujuan dari kegiatan gotong royong agar jalan raya Desa Batutulis menjadi bersih, hal ini untuk mewujudkan kampung sehat. Kegiatan ini dilakukan pada pagi hari bersama Kepala Desa Batutulis, Babinza,

Suparmanto, dkk (2021), Keterlibatan KKP-DR UIN Mataram pada masa pandemi ... | Vol. 01, No.02, 2021 | h. 65 
Kepala Dusun, dan masyarakat. Kegiatan ini dilakukan dari perbatasan Dusun Jerneng hingga ke Depan Kantor Batutulis.

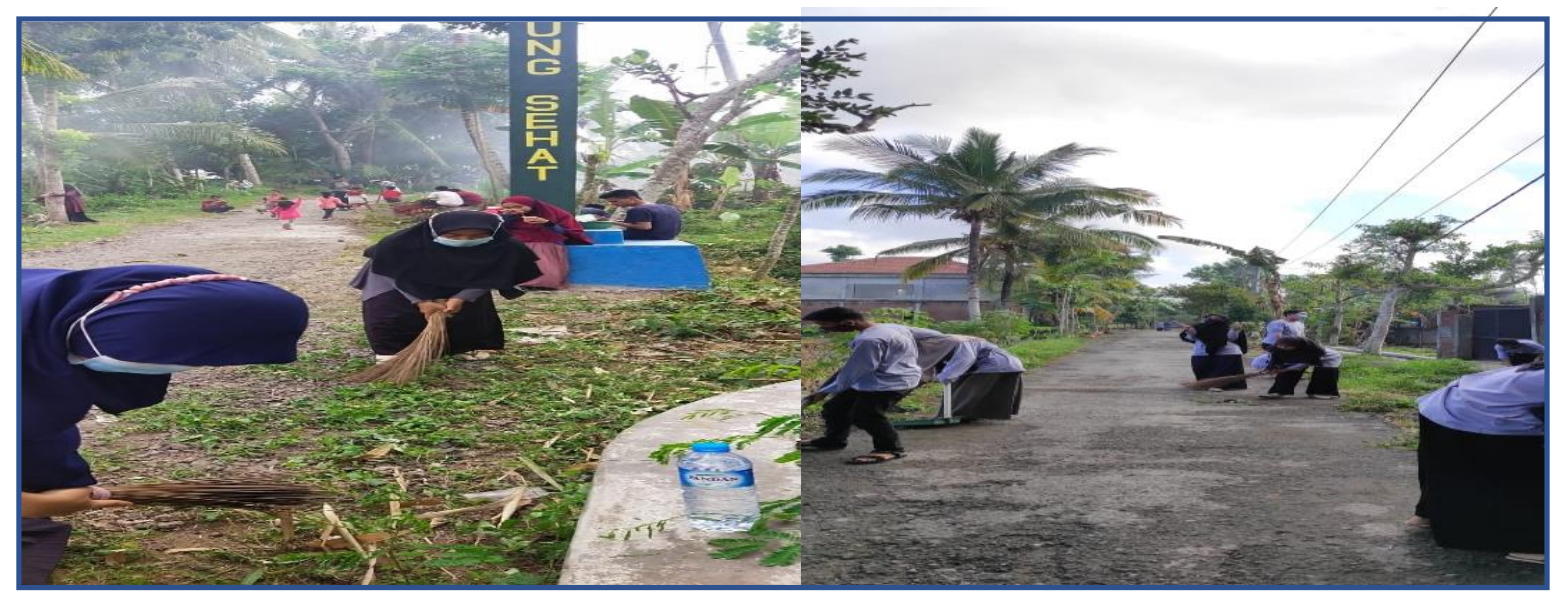

Gambar 6: Gotong royong di sepanjang jalan Dusun Batutulis

\section{Bersih-bersib masjid dan musholla}

Kegiatan ini adalah kegiatan rutin yang dilakukan setiap minggu, yakni setiap hari jum'at. Kegiatan ini dilakukan pada pagi hari sedengan musholla dan masjid yang akan dibersihkan secara bergilir setiap minggunya. Kegitan ini mengikutsertakan masyarakat setempat agar menumbuhkan kepedulian untuk menjaga kebersihan di tempat ibadah dan menumbuhkan semagat kerja sama. Adapun sejumlah masjid dan musholla yang telah dilakukan pembersihan yaitu Masjid Darul Iman Dusun Bangket Gawah, pembersihan Musholla Al-Kautsar Dusun Jerneng, Masjid Al- Daruttauhid Dusun Jerneng dan masjid lainnya. Tujuan dari kegiatan ini untuk menjadikan tempat ibadah yang nyaman dan bersih sehinggadapat memutus penyebaran Covid-19. Kegiatan membersihkan masjid dan musholla ini meliputi menyapu dan mengempel area bangunan dan tempat berwudhu, membersihkan jendala, menjemur karpet masjid.

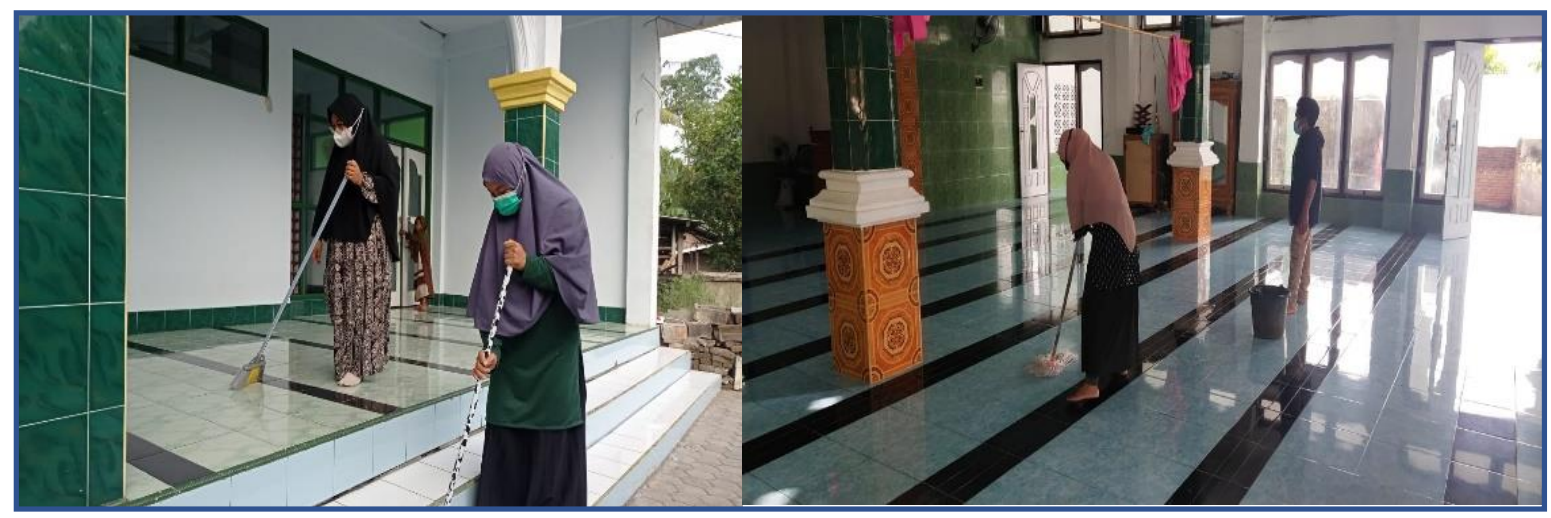

Gambar 7: Bersih-bersih masjid dan musholla

Suparmanto, dkk (2021), Keterlibatan KKP-DR UIN Mataram pada masa pandemi ... | Vol. 01, No.02, 2021 | h. 66 
Pembuatan dan pemasangan plang larangan membuang sampah sembarangan serta pembersihan sungai

Tujuan pembuatan dan pemasangan plang ini agar masyarakat tidak membuang sampah sembarangan, terutama di sungai dan selokan. Hal ini merupakan langkah untuk mewujudkan kampung sehat yang memang merupakan program dari kepala Desa. Masyarakat di Dusun Bangkat Gawah masih lalai untuk membuang sampah pada tempatnya. Masyarakat membuang sampah ke sungai terutama sampah non organik seperti popok bayi yang akibatnya berdampak pada musim penghujan. Saat musim penghujan aliran sungai terhambat, air sungai pun meluap dan menyebabkan banjir. Oleh karena itukegiatan pembuatan pelang ini juga dibarengi dengan pembersihan lingkungan serta sungai di bangkat gawah dengan mengikutsertakan masyarakat.

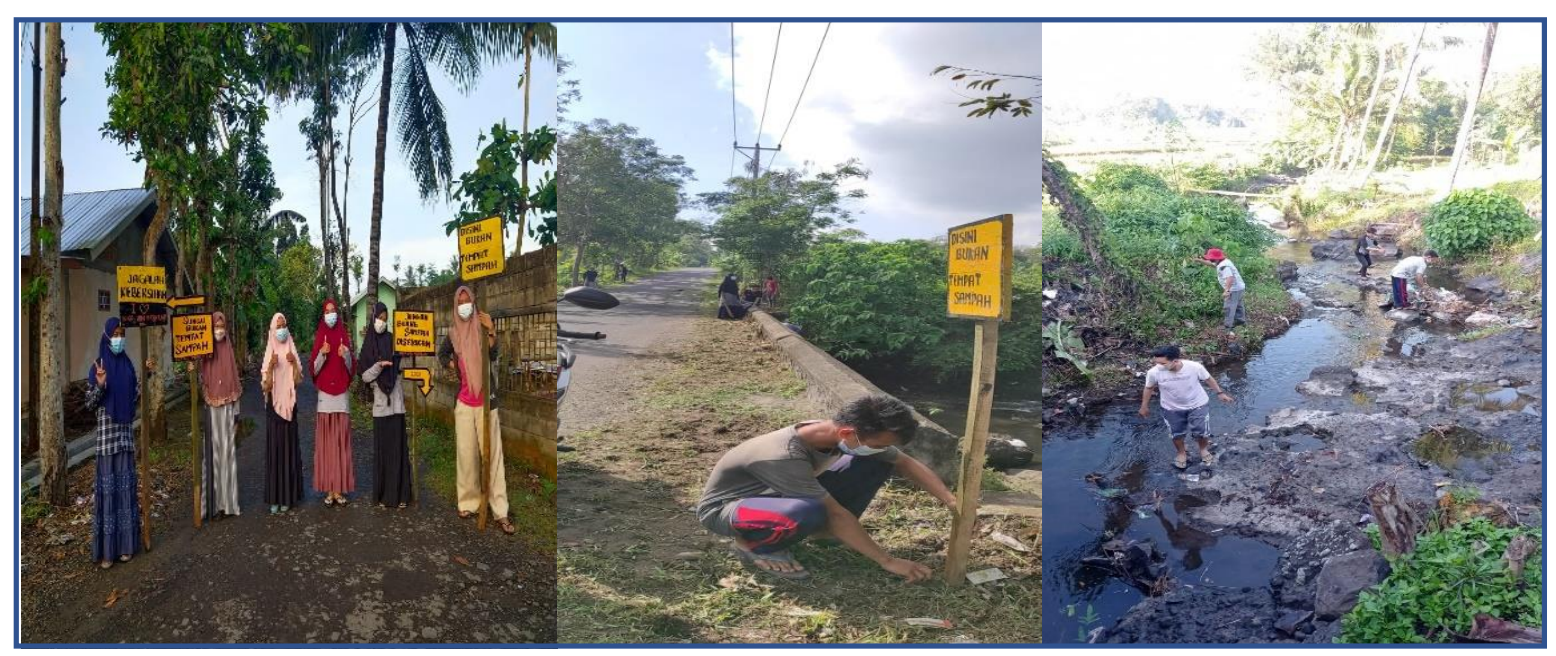

Gambar 8: Pembuatan dan pemasangan plang larangan membuang sampah sembarangan serta pembersihan sungai

\section{Pembuatan taman mini}

Pembuatan taman mini dilakukan di Dusun Bangket Gawah. Pembuatan taman mini adalah salah satu cara untuk mewujudkan kampung sehat. Proses pembuatan taman mini memakan waktu satu minggu. Pembuatan taman mini diawali dengan pembuatan pagar, kemudian pembuatan plang untuk taman, dilanjutkan dengan penanaman bunga, dan terakhir pengecatan pagar dan batu hiasan untuk pot bunga Tujuan pembuatan taman mini yakni agar menambah spot wisata di Dusun Bangket Gawah serta terciptanya lingkungan yang sejuk.

Suparmanto, dkk (2021), Keterlibatan KKP-DR UIN Mataram pada masa pandemi ... | Vol. 01, No.02, 2021 | h. 67 


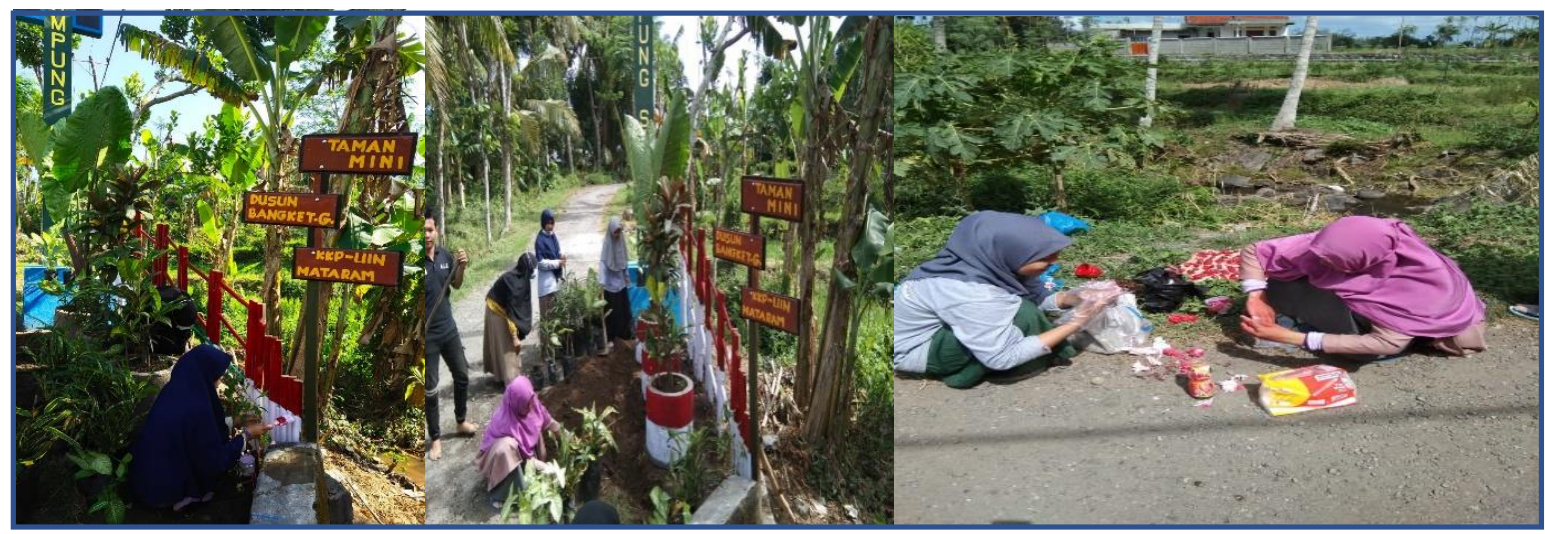

Gambar 9: Pembuatan taman mini

\section{Penanaman 100 Pohon}

Mahasiswa beserta masyarakat setempat melakukan gerakan menanam 100 pohon. Sebelumnya kami mengajukan untuk perolehan bibit pohon mahoni di Dinas Lingkungan Hidup dan Kehutanan. Penanaman pohon dilakukan di sepanjang jalan Desa Batutulis. Tujuan penanaman pohon ini agar lingkungan Desa Batutulis menjadi lebih asri serta menjaga udara tetap bersih mengigiat kebiasaan masyarakat yang sering membakar sampah. Dengan adanya penanaman pohon ini bisa meminimalisir adanya polusi udara.

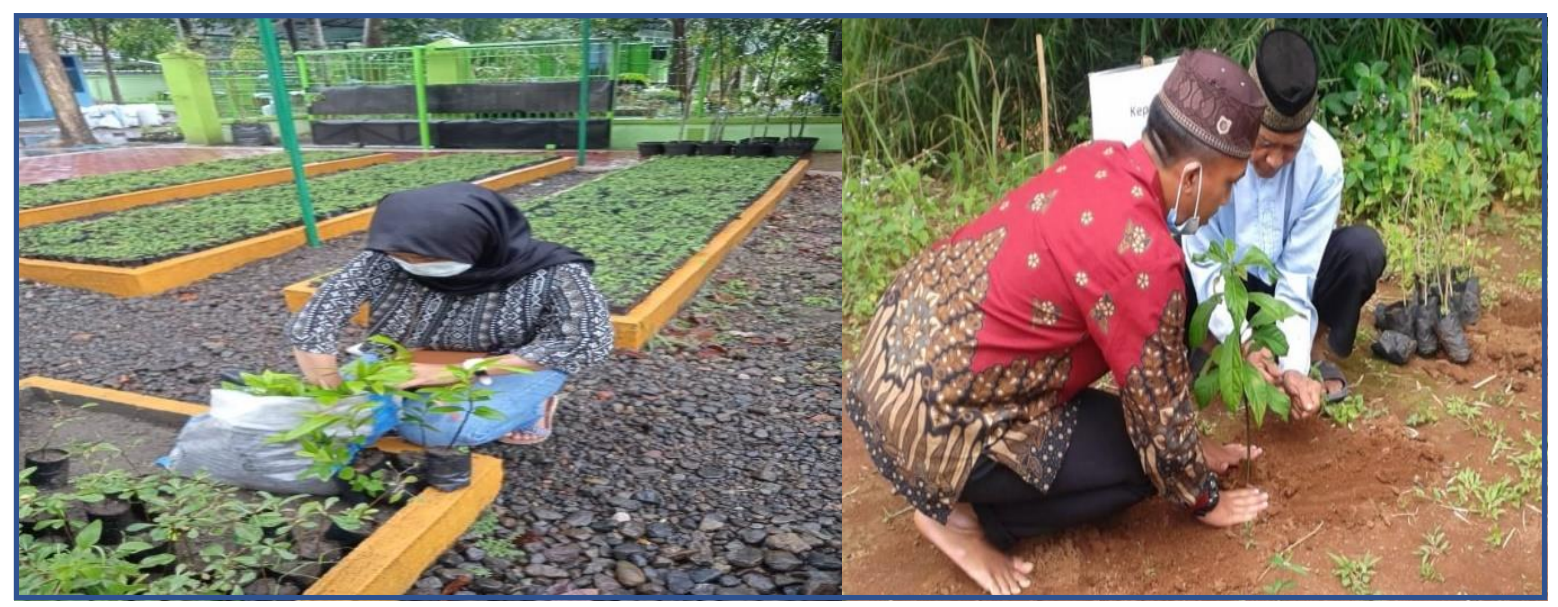

Gambar 10: Penanaman 100 pohon

\section{Kesimpulan}

UIN Mataram sebagai bagian dari Lembaga pemerintah di bawah Lingkungan Kementeriaan Keagamaan Republik Indonesia ikut terlibat dan berperan aktif dalam membantu masyarakat dan pemerintah menanggulangi pandemic Covid-19. Serta berperan untuk memecahkan permasalahan yang ada di masyarakat.

Program KKP-DR atau Kuliah Kerja Partisipatif dari Rumah merupakan salah satu strategi yang dilakukan oleh UIN Mataram. Melalaui KKP-DR, UIN Mataram berupaya

Suparmanto, dkk (2021), Keterlibatan KKP-DR UIN Mataram pada masa pandemi ... | Vol. 01, No.02, 2021 | h. 68 
mensinergikan programnya dengan program pemerintah dalam membantu percepatan penangan dan pencegahan penyebaran Covid-19. UIN Mataram mengerahkan keterlibatan yang dapat bersentuhan dengan masyarakat melalui program KKP-DR ini. Berbagai program, strategi dan kebijakan pun diambil agar bisa berdampak positif terhadap masyarakat.

Salah satu lokasi KKP-DR, yaitu di Desa Batutulis Kecamatan Jonggat Kabupaten Lombok Tengah. upaya dilakukan oleh mahasiswa pada aspek kesehatan. Mengingat di Desa Batu Tulis terdapat masyarakat yang terpapar Covid-19 dan aspek kesehatan ini juga berkaitan dengan tujuan dari Kepala Desa Batutulis untuk mewujudkan kampung sehat. Tujuan dari adanya kampung sehat adalah menciptakan suatu masyarakat yang mandiri untuk hidup sehat melalui kampung sehat yang berbasis perilaku hidup bersih dan sehat. Selain itu juga untuk memberdayakan anggota rumah tangga agar tahu, mau, dan mampu mempraktekkan perilaku hidup bersih dan sehat serta berperan aktif dalam gerakan kesehatan di masyarakat. Karena memang masyarakat di Desa Batutulis masih memiliki kebiasaan untuk membuang sampah sembarangan di selokan dan terutama di sungai. Sungai di Desa Batuttulis yang dulunya dikenal bersih dan digunakan sembagai tempat menyunyi baju dan mandi oleh masyarakat kini telah burubah menjadi sungai yang kotor. Sungai banyak tercermari oleh sampah plastic serta sampah popok bayi. Akibatnya pada musim penghujan aliran air sungai terhambat dan menyebabkan banjir.

Keterlibatan mahasiswa KKP-DR UIN Mataram pada masa pandemic Covid-19 cukup berpengaruh dalam mewujudkan kampung sehat di Desa Batutulis. Pengaruh yang dimaksud adalah mulai timbulnya kesadaran masyarakat untuk menjaga kebersihan dengan tidak membuang sampah sembarangan terutama di selokan dan sungai. Beberapa upaya yang dilakukan untuk pencegahan penyebaran virus Covid-19 yaitu penyebaran pamflet, pembagian masker, pembagian hand sanitizer, sosialisasi cara mencuci tangan yang baik dan benar, serta melakukan kegiatan senam sehat. Adapun upaya untuk mewujudkan kampung sehat yaitu gotong royong di sepanjang jalan, pembersihan masjid dan musholla, pembuatan dan pemasangan plang larangan membuang sampah sembarangan serta pembersihan sungai, pembuatan taman mini, dan penanaman 100 pohon.

\section{Ucapan Terima Kasih}

Ucapan terimakasih yang mendalam kepada Dosen Pembimbing Lapangan (DPL) yang telah mengarahkan dan membimbing kami selama kegiatan KKP dan terimaksih juga kepada LP2M UIN Mataram yang sudah mendukung terselenggaranya kegiatan pengabdian pada masyarakat melalui program KKP-DR.

\section{Daftar Pustaka}

Budioro. 1998. Pengukur Pendidikan (Penyuluban) Keseahatan Masyarakat. Semarang: Undip Press.

Suparmanto, dkk (2021), Keterlibatan KKP-DR UIN Mataram pada masa pandemi ... | Vol. 01, No.02, 2021 | h. 69 
Fardhiasih, D.S., Suryani,d...2018. Faktor-faktoryang berbubungan dengan Perilaku Hidup Bersih dan Sehat ada Pedagang Angkringan di Kawasan Malioboro Yogyakarta. Jurnal Kesehatan Masyarakat, Vol. 3, No.3.

Gita, 2018. Faktor-faktor yang Mempengarubi Hidup Bersih dan Sehat, Jurnal Sainmed, Vol.14 No. 1 Juni 2018.

Iskriyanti, Hari. 2002. Hubungan Karakteristik, Pengetabuan dan Sikap Tentang PHBS dengan Praktek. Kesehatan Keluarga dan Kesehatan Lingkungan di Kelurahan Rejowinangun Kecamatan Kota Gede Kota Jakarta Agustus 2002. Semarang: UNDIP.

Kampung Sehat Kota Tangerang, Antara Banten, diakses pada tanggal, 15 Agustus 2021 https:// banten.antaranews.com/berita/24704/kampung-sehat-kota-tanngerang

Kemenkes RI. 2016. Perilaku Hidup Bersih dan Sehat (PHBS). Diakses pada tanggal, 15 Agustus 2021 http://promkes.kemkes.go.id/phbs.

Kemenkes RI. 2020. Tanya Jawab Corona Virus Disiase (COVID-19). Diakses pada tanggal 15 Agustus 2021. https://covid19.kemkes.go.id

Notoatmodjo, S. 2003. Pendidikan dan Perilaku Kesehatan. Jakarta: rineka cipta, 16, 15-49.

Notoatmodjo, S. 2007. Promosi Kesehatan dan Ilmu Perilaku. Jakarta: Rineka Cipta.

Tim P2M LP2M UIN Mataram. 2021. Buku Panduan Kuliah Kerja Partisipatif 2021: Penanggulangan Covid-19 Berbasis Moderasi Beragama. Mataram: P2M LP2M UIN Mataram.

World Health Organization. 2020. Coronavirus (COVID-19). Diakses pada tanggal 15 Agustus 2021. https://covid-19.who.int/.

Yuliana. 2020. Corona Virus Diseases (COVID-10). Wellness and Healthy Magazine. Fakultas Kedokteran Universitas Lampung. Vol 2, No 1, p.187-192.

Suparmanto, dkk (2021), Keterlibatan KKP-DR UIN Mataram pada masa pandemi ... | Vol. 01, No.02, 2021 | h. 70 